\title{
Vibrational spectroscopic study of the uranyl selenite mineral derriksite $\mathrm{Cu}_{4} \mathrm{UO}_{2}\left(\mathrm{SeO}_{3}\right)_{2}(\mathrm{OH})_{6} \cdot \mathrm{H}_{2} \mathrm{O}$
}

\author{
Ray L. Frost ${ }^{a}$,*, Jiří Čejka ${ }^{b}$, Ricardo Scholz ${ }^{c}$, Andrés López ${ }^{a}$, Frederick L. Theiss ${ }^{a}$, Yunfei Xi ${ }^{a}$

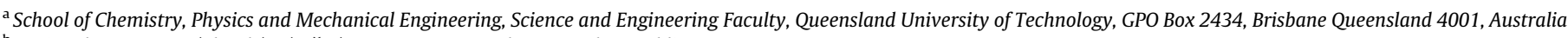 \\ b National Museum, Václavské náměstí 68, CZ-115 79 Praha 1, Czech Republic

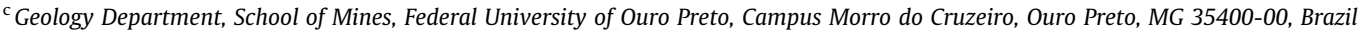

\section{H I G H L I G H T S}

- We have studied the mineral derriksite $\mathrm{Cu}_{4} \mathrm{UO}_{2}\left(\mathrm{SeO}_{3}\right)_{2}(\mathrm{OH})_{6} \cdot \mathrm{H}_{2} \mathrm{O}$.

- A comparison was made with the other uranyl selenites.

- Namely demesmaekerite, marthozite, larisaite, haynesite and piretite.

- Approximate U-O bond lengths in uranyl and $\mathrm{O}-\mathrm{H} \cdots \mathrm{O}$ hydrogen bond lengths were calculated.

\section{G R A P H I C A L A B S T R A C T}



\section{A R T I C L E I N F O}

\section{Article history:}

Received 20 May 2013

Received in revised form 29 July 2013

Accepted 2 August 2013

Available online 22 August 2013

\section{Keywords:}

Derriksite

Selenite

Raman spectroscopy

Infrared spectroscopy

Uranyl

$\mathrm{U}-\mathrm{O}$ bond lengths

\begin{abstract}
A B S T R A C T
Raman spectrum of the mineral derriksite $\mathrm{Cu}_{4} \mathrm{UO}_{2}\left(\mathrm{SeO}_{3}\right)_{2}(\mathrm{OH})_{6} \cdot \mathrm{H}_{2} \mathrm{O}$ was studied and complemented by the infrared spectrum of this mineral. Both spectra were interpreted and partly compared with the spectra of demesmaekerite, marthozite, larisaite, haynesite and piretite. Observed Raman and infrared bands were attributed to the $\left(\mathrm{UO}_{2}\right)^{2+},\left(\mathrm{SeO}_{3}\right)^{2-},(\mathrm{OH})^{-}$and $\mathrm{H}_{2} \mathrm{O}$ vibrations. The presence of symmetrically distinct hydrogen bonded molecule of water of crystallization and hydrogen bonded symmetrically distinct hydroxyl ions was inferred from the spectra in the derriksite unit cell. Approximate U-O bond lengths in uranyl and $\mathrm{O}-\mathrm{H} \cdots \mathrm{O}$ hydrogen bond lengths were calculated from the Raman and infrared spectra of derriksite.
\end{abstract}

(c) 2013 Elsevier B.V. All rights reserved.

\section{Introduction}

The crystal chemistry of selenium(IV) oxo-compounds shows great structural versatility expressed by the great number of different compounds [1]. Crystallochemical systematics of selenites was presented by Serezhkina et al. [2].

\footnotetext{
* Corresponding author. Tel.: +61 73138 2407; fax: +61 731381804 .

E-mail address: r.frost@qut.edu.au (R.L. Frost).
}

Uranyl anion topology of uranyl natural and synthetic compounds inclusive of uranyl selenites has been elaborated by Burns [3-6]. According to Finch and Murakami [7], uranyl selenites occur where Se-bearing sulfide minerals are undergoing oxidation and dissolution. Derriksite, demesmaekerite, guilleminite and marthozite are from the Musonoi $\mathrm{Cu}-\mathrm{Co}$ mine, near Kalwezi, Katanga Province, Democratic Republic of Congo, piretite and also guilleminite from Shinkolobwe, Katanga Province, Democratic Republic of Congo, haynesite and larisaite from the Repete mine, San Juan Co., Utah, U.S.A $[8,9]$. 
Structures of derriksite, $\mathrm{Cu}_{4} \mathrm{UO}_{2}\left(\mathrm{SeO}_{3}\right)_{2}(\mathrm{OH})_{6} \cdot \mathrm{H}_{2} \mathrm{O}[10,11]$, and demesmaekerite, $\mathrm{Pb}_{2} \mathrm{Cu}_{5}\left[\left(\mathrm{UO}_{2}\right)\left(\mathrm{SeO}_{3}\right)_{3}\right]_{2}(\mathrm{OH})_{6} \cdot\left(\mathrm{H}_{2} \mathrm{O}\right)_{2}$, are characterized by infinite chains formed from uranyl and selenite ions [6,12], while those of the remaining uranyl selenite minerals, guilleminite, $\mathrm{Ba}\left[\left(\mathrm{UO}_{2}\right)_{3} \mathrm{O}_{2}\left(\mathrm{SeO}_{3}\right)_{2}\right] \cdot\left(\mathrm{H}_{2} \mathrm{O}\right)_{3}[13]$, marthozite, $\mathrm{Cu}\left[\left(\mathrm{UO}_{2}\right)_{3}-\right.$ $\left.\mathrm{O}_{2}\left(\mathrm{SeO}_{3}\right)_{2}\right]\left(\mathrm{H}_{2} \mathrm{O}\right)_{8}$ [14], larisaite, $\mathrm{Na}\left(\mathrm{H}_{3} \mathrm{O}\right)\left[\left(\mathrm{UO}_{2}\right)_{3}\left(\mathrm{SeO}_{3}\right)_{2} \mathrm{O}_{2}\right]\left(\mathrm{H}_{2} \mathrm{O}\right)_{4}$ [9] and probably also haynesite, $\left[\left(\mathrm{UO}_{2}\right)_{3}\left(\mathrm{SeO}_{3}\right)_{2}(\mathrm{OH})_{2}\right] \cdot\left(\mathrm{H}_{2} \mathrm{O}\right)_{5}$ $[15,16]$ and piretite, $\mathrm{Ca}\left[\left(\mathrm{UO}_{2}\right)_{3}\left(\mathrm{SeO}_{3}\right)_{2}(\mathrm{OH})_{4}\right] \cdot\left(\mathrm{H}_{2} \mathrm{O}\right)_{4}$ [16] by uranyl oxo-hydroxo selenite sheets and phosphuranylite anion sheet topology. According to Chukanov et al. [9], the general formula of the minerals guilleminite, marthozite, haynesite, piretite and larisaite is $\mathrm{M}_{0-1}\left[\left(\mathrm{UO}_{2}\right)_{3}\left(\mathrm{SeO}_{3}\right)_{2}(\mathrm{O}, \mathrm{OH})_{2-4}\right] \cdot n \mathrm{H}_{2} \mathrm{O}$, where $a=3-8$, $\mathrm{M}=\mathrm{M}^{2+}, 2 \mathrm{M}^{+}$. In derriksite, the uranyl coordination polyhedra are formed from tetragonal (square) dipyramids $\mathrm{UO}_{2} \mathrm{O}_{4}$, in demesmaekerite pentagonal dipyramids $\mathrm{UO}_{2} \mathrm{O}_{5}$, and probably in all remaining natural uranyl selenites from pentagonal and hexagonal dipyramids $\mathrm{UO}_{2} \mathrm{O}_{5}$ and $\mathrm{UO}_{2} \mathrm{O}_{6}$, respectively similarly as in phosphuranylite. According to Ginderow and Cesbron [11], derriksite contains the brucite-type layers of $\mathrm{CuO}_{6}$. Derriksite is structurally related to deloryite, $\mathrm{Cu}_{4}\left(\mathrm{UO}_{2}\right)\left(\mathrm{MoO}_{4}\right)_{2}(\mathrm{OH})_{6}$ and the difference in space group between the two minerals is the direct consequence of the replacement of the $\mathrm{SeO}_{3}$ trigonal pyramids in derriksite by the $\mathrm{MoO}_{4}$ tetrahedra in deloryite. Deloryite does not contain any molecular water. This differs from derriksite containing one water molecule. Ginderow and Cesbron [11] inferred from thermogravimetric curve (TGA) presented by Cesbron et al. [10], that the first dehydration step (up to approximately $300^{\circ} \mathrm{C}$ ) may be connected with adsorbed water. However, the original Cesbron's interpretation that this first TGA step corresponds with one molecule of water of crystallization [10] seems to be more correct.

Raman spectroscopy was proven most useful for the characterization of secondary uranyl containing minerals [17-23]. The aim of this research is the study of Raman spectra of the natural uranyl selenite derriksite, complemented by its infrared spectra. The paper is a part of systematic vibrational spectroscopic research of secondary minerals formed in the oxidation zone, inclusive uranyl minerals originating during hydration-oxidation weathering of primary uranium minerals, such as uraninite. Raman spectroscopy was proven most useful for the characterization of secondary uranyl containing minerals. In order to identify and characterize the Raman and infrared spectra of derriksite, this research reports the Raman and infrared spectrum of derriksite and relates the spectra of derriksite to the structure of the mineral.

\section{Experimental}

\section{Mineral}

For the development of this work, one single crystal of derriksite was chosen for our investigation. Sample was obtained from the collection of the Geology Department of the Federal University of Ouro Preto, Minas Gerais with sample code SAB-098. The crystal is deep green and transparent, with up to $2.0 \mathrm{~mm}$ in length and occurs in association with malachite. The studied sample is from Musonoi Mine, Katanga, Democratic Republic of Congo and can be considered a type material.

The chemical analyses of the mineral have been made. These are included in Supplementary information.

\section{Raman microprobe spectroscopy}

Crystals of derriksite were placed on a polished metal surface on the stage of an Olympus BHSM microscope, which is equipped with $10 \times, 20 \times$, and $50 \times$ objectives. The microscope is part of a Renishaw 1000 Raman microscope system, which also includes a monochromator, a filter system and a CCD detector (1024 pixels). The Raman spectra were excited by a Spectra-Physics model 127 He-Ne laser producing highly polarized light at $633 \mathrm{~nm}$ and collected at a nominal resolution of $2 \mathrm{~cm}^{-1}$ and a precision of $\pm 1 \mathrm{~cm}^{-1}$ in the range between 200 and $4000 \mathrm{~cm}^{-1}$. Repeated acquisitions on the crystals using the highest magnification $(50 \times)$ were accumulated to improve the signal to noise ratio of the spectra. Raman Spectra were calibrated using the $520.5 \mathrm{~cm}^{-1}$ line of a silicon wafer. The Raman spectrum of at least 10 crystals was collected to ensure the consistency of the spectra.

\section{Infrared spectroscopy}

Infrared spectra were obtained using a Nicolet Nexus 870 FTIR spectrometer with a smart endurance single bounce diamond ATR cell. Spectra over the $4000-525 \mathrm{~cm}^{-1}$ range were obtained by the co-addition of 128 scans with a resolution of $4 \mathrm{~cm}^{-1}$ and a mirror velocity of $0.6329 \mathrm{~cm} / \mathrm{s}$. Spectra were co-added to improve the signal to noise ratio. The infrared spectra are given in the supplementary information.

Spectral manipulation such as baseline correction/adjustment and smoothing were performed using the Spectracalc software package GRAMS (Galactic Industries Corporation, NH, USA). Band component analysis was undertaken using the Jandel 'Peakfit' software package that enabled the type of fitting function to be selected and allows specific parameters to be fixed or varied accordingly. Band fitting was done using a Lorentzian-Gaussian cross-product function with the minimum number of component bands used for the fitting process. The Gaussian-Lorentzian ratio was maintained at values greater than 0.7 and fitting was undertaken until reproducible results were obtained with squared correlations of $r^{2}$ greater than 0.995 .

\section{Results and discussion}

The Raman spectrum of derriksite over the full wavenumber range is illustrated in Fig. 1a. This figure displays the position and relative intensities of the Raman bands of derriksite. It may be observed that there are large parts of the spectrum where no intensity is found; therefore the spectrum is subdivided into sections based upon the type of vibration being studied. The infrared spectrum of derriksite over the full wavenumber range is illustrated in Fig. 1b. This spectrum shows the position and relative intensities of the infrared bands of derriksite. The Raman spectrum of derriksite over the 700 to $1400 \mathrm{~cm}^{-1}$ spectral range is reported in Fig. 2a. The infrared spectrum of derriksite over the 600 to $1400 \mathrm{~cm}^{-1}$ spectral range is reported in Fig. 2b. The Raman spectra of derriksite over the 300 to $700 \mathrm{~cm}^{-1}$ and 100 to $300 \mathrm{~cm}^{-1} \mathrm{spec}$ tral ranges are reported in Fig. 3. The Raman and infrared spectra of the $\mathrm{OH}$ stretching region $\left(2600-4000 \mathrm{~cm}^{-1}\right)$ are shown in Fig. 4. The Raman and infrared spectra in the water bending region (1300-1800 $\mathrm{cm}^{-1}$ ) are given in Fig. 5 .

The free linear uranyl group $\left(\mathrm{UO}_{2}\right)^{2+}$, symmetry $D_{\infty h}$, has four normal vibrations, but only three fundamentals: the $v_{1}$ symmetric stretching vibration, Raman active (approximately $900-700 \mathrm{~cm}^{-1}$ ), the $v_{2}(\delta)$ doubly degenerate bending vibration, infrared active (approximately $300-200 \mathrm{~cm}^{-1}$ ), and the $v_{3}$ antisymmetric stretching vibration, infrared active (approximately $1000-850 \mathrm{~cm}^{-1}$ ). Distortion of the uranyl group or change in the local symmetry can result in the removal of the degeneracy and therefore Raman activation of the $v_{2}$ mode and infrared activation of the $v_{1}$ mode [24].

The chemistry of the selenite ion and selenite containing compounds resembles the chemistry of the sulphite ion and its compounds. The polyhedron of the selenite ions is similar to that of sulphite ions, which is trigonal pyramid with one vacant orbital 

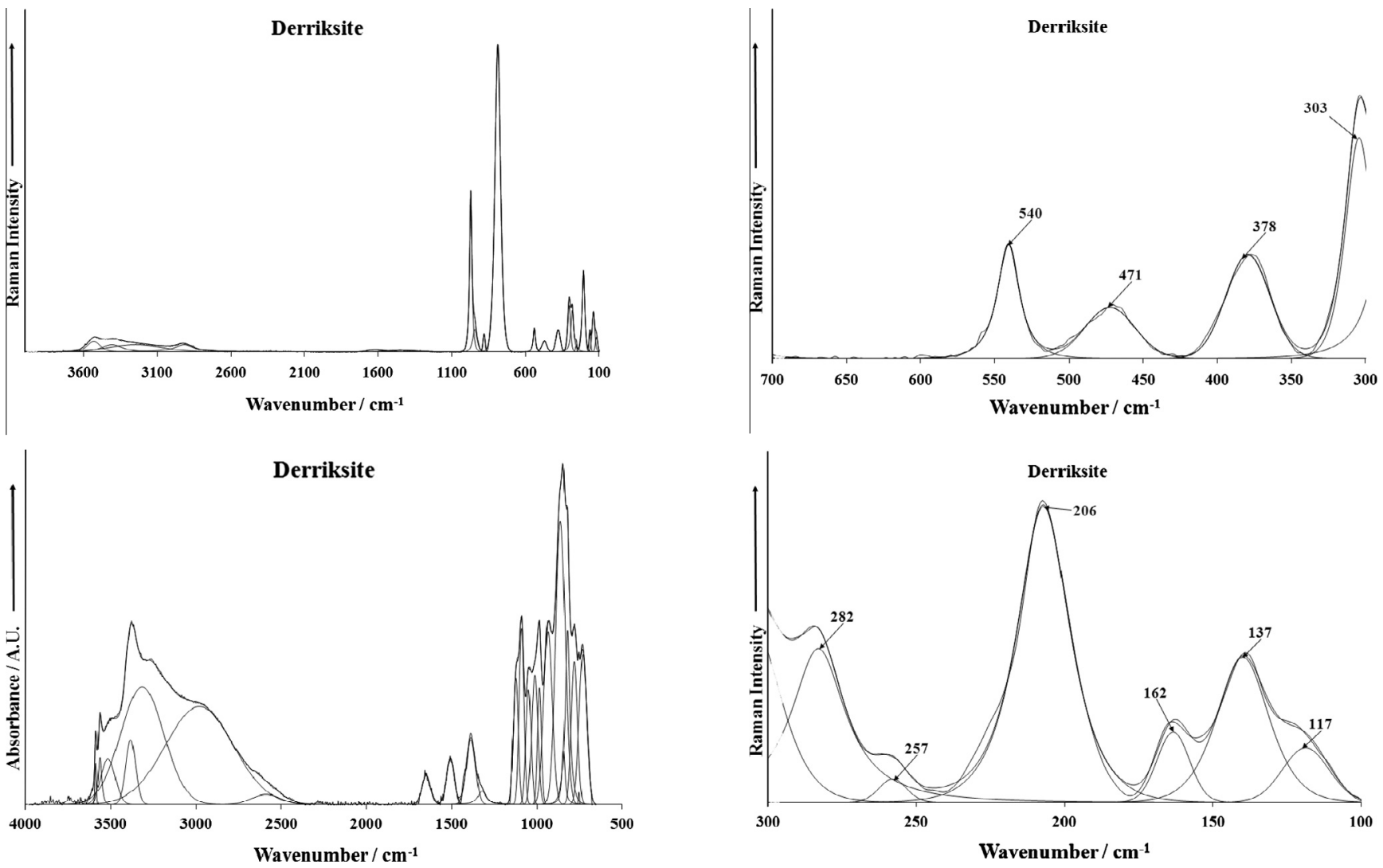

Fig. 1. (a) Raman spectrum of derriksite over the 100 to $4000 \mathrm{~cm}^{-1}$ spectral range. (b) Infrared spectrum of derriksite over the 500 to $4000 \mathrm{~cm}^{-1}$ spectral range.

Fig. 3. (a) Raman spectrum of derriksite over the 300 to $800 \mathrm{~cm}^{-1}$ spectral range. (b) Raman spectrum of derriksite over the 100 to $300 \mathrm{~cm}^{-1}$ spectral range.
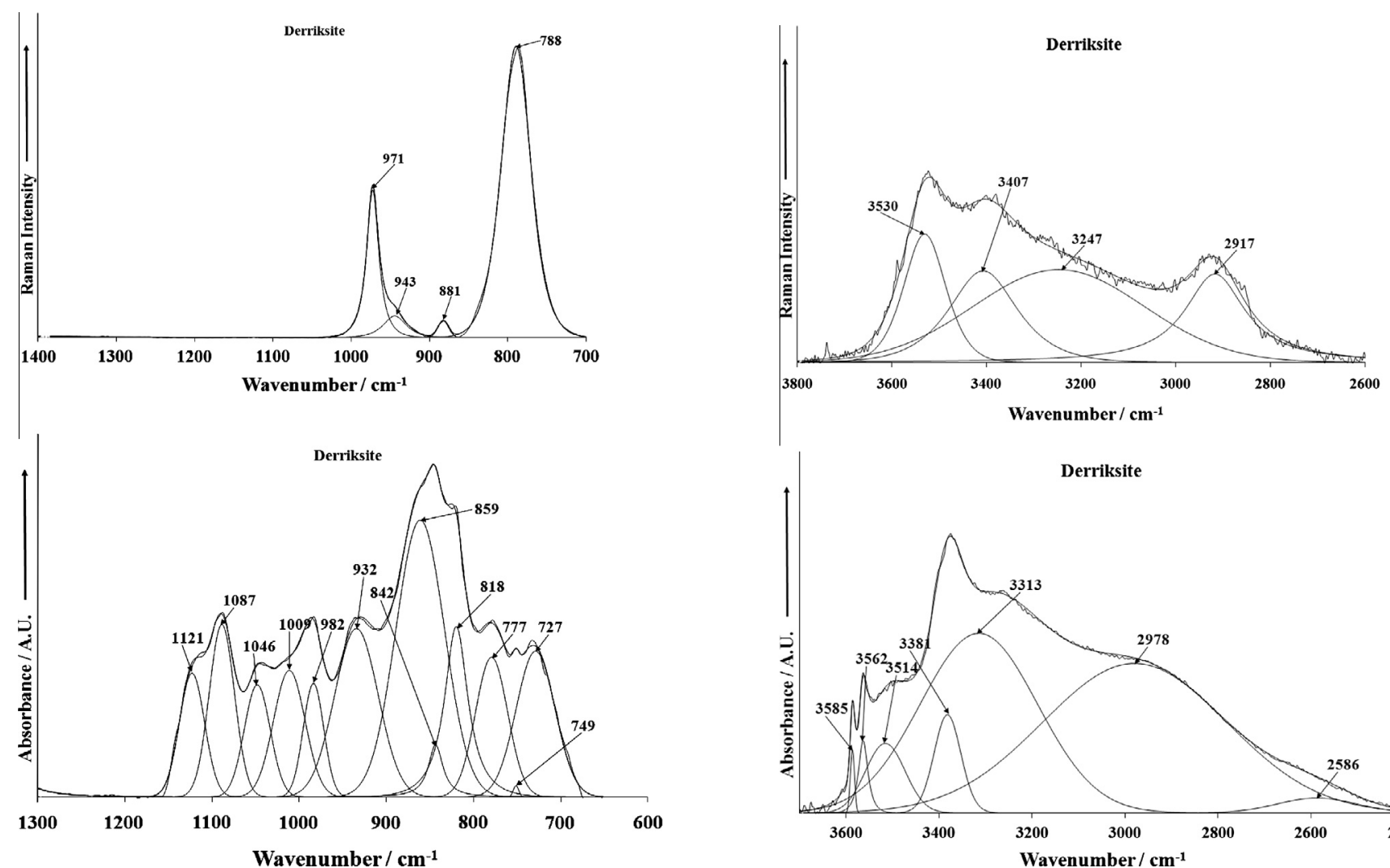

Fig. 2. (a) Raman spectrum of derriksite over the 800 to $1400 \mathrm{~cm}^{-1}$ spectral range. (b) Infrared spectrum of derriksite over the 500 to $1300 \mathrm{~cm}^{-1}$ spectral range.

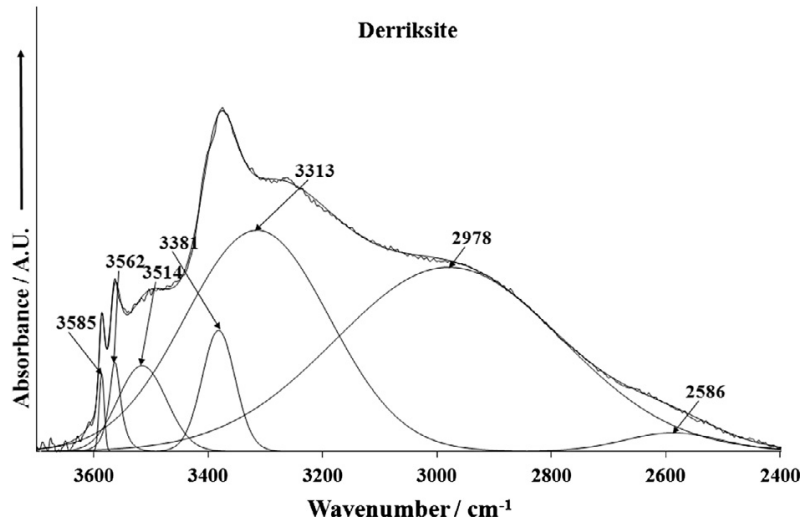

Fig. 4. (a) Raman spectrum of derriksite over the 2600 to $4000 \mathrm{~cm}^{-1}$ spectral range. (b) Infrared spectrum of derriksite over the 2600 to $4000 \mathrm{~cm}^{-1}$ spectral range. 

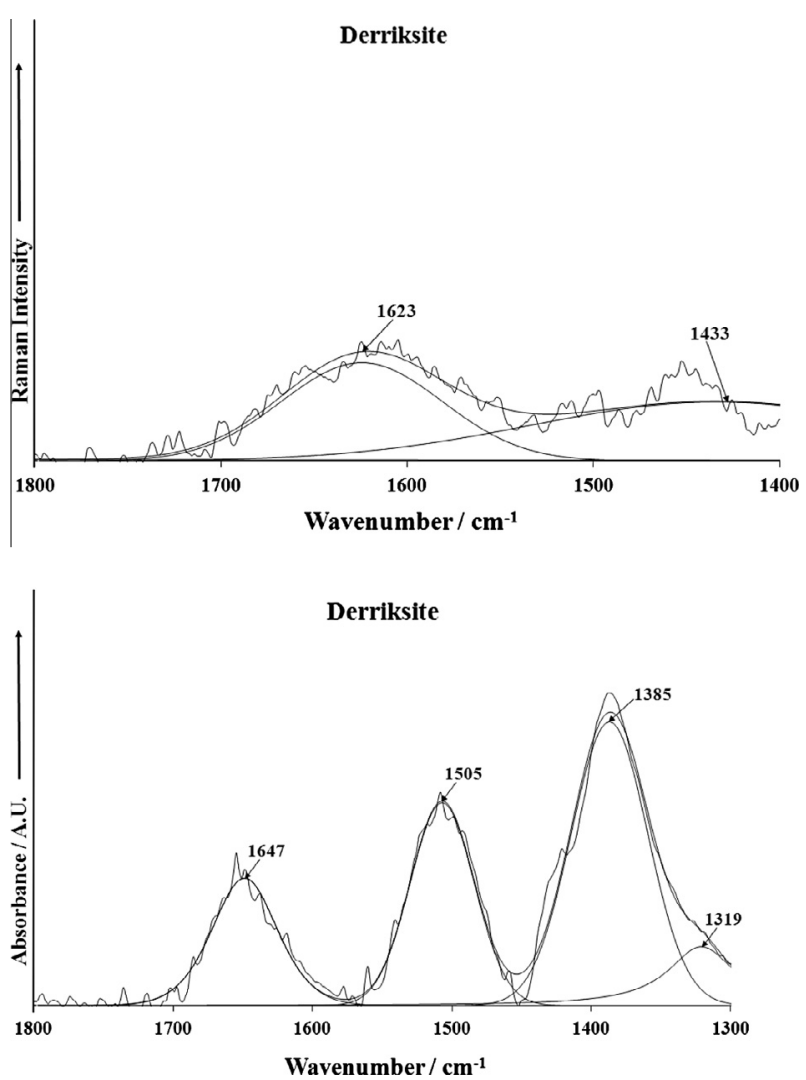

Fig. 5. (a) Raman spectrum of derriksite over the 1300 to $1800 \mathrm{~cm}^{-1}$ spectral range. (b) Infrared spectrum of derriksite over the 1300 to $1800 \mathrm{~cm}^{-1}$ spectral range.

thus making $C_{3 v}$ symmetry [25]. The selenite ion $\left(\mathrm{SeO}_{3}\right)^{2-}$ has four fundamentals: the $v_{1}$ symmetric stretching vibrations (approximately $790-806$ or $760-855 \mathrm{~cm}^{-1}$, the $v_{2}$ symmetric bending vibration (approximately $430-461 \mathrm{~cm}^{-1}$ ), the $v_{3}$ doubly degenerate antisymmetric stretching vibration (714-769 or 680$775 \mathrm{~cm}^{-1}$ ), and the $v_{4}$ doubly degenerate antisymmetric bending vibration (approximately $387-418 \mathrm{~cm}^{-1}$ ). All vibrations are Raman and infrared active [26-29]. The degeneracy of the antisymmetric $v_{3}$ and $v_{4}$ modes of the $\left(\mathrm{SeO}_{3}\right)^{2-}$ may be removed due to the lowering of its site symmetry in the unit cell.

In the crystal structure of orthorhombic derriksite (S.G. $P n 2_{1} m=C_{2 v}^{7}$, a 5.570(2), b 19.088(8), c $5.965 \AA$ ), there are one symmetrically distinct $\mathrm{U}^{6+}$, two symmetrically distinct $\mathrm{Se}^{4+}$, three symmetrically distinct $\mathrm{Cu}^{2+}$, six symmetrically distinct $\mathrm{O}^{2-}$ and four symmetrically distinct $\mathrm{OH}^{-}, Z=2$ [11].

Raman band at $788 \mathrm{~cm}^{-1}$ and an infrared band at $818 \mathrm{~cm}^{-1}$ are assigned to the $v_{1}\left(\mathrm{UO}_{2}\right)^{2+}$ symmetric stretching vibrations, however, both bands coincide with the $v_{1}\left(\mathrm{SeO}_{3}\right)^{2-}$ symmetric stretching mode. No Raman band was attributed to the $v_{3}\left(\mathrm{UO}_{2}\right)^{2+}$ antisymmetric stretching vibration. An infrared band at $859 \mathrm{~cm}^{-1}$ is assigned to the $v_{3}\left(\mathrm{UO}_{2}\right)^{2+}$ antisymmetric stretching vibration. Approximate $\mathrm{U}-\mathrm{O}$ bond lengths in uranyl were calculated with two empirical relations using wavenumbers of the stretching uranyl vibrations, i.e. $\mathrm{R}_{\mathrm{U}-\mathrm{O}}=0.575+106.5 v_{1}^{-2 / 3} \mathrm{~A}$, and $\mathrm{R}_{\mathrm{U}-\mathrm{O}}=$ $0.804+91.41 v_{3}^{-2 / 3} \mathrm{~A}$, published by Bartlett and Cooney [30]. Obtained calculated $\mathrm{U}-\mathrm{O}$ bond lengths $\left(\AA / \mathrm{cm}^{-1}\right)$ 1.823/788, $1.793 / 818$ and $1.816 / 859$ are close to the average $U-O$ bond length $1.795 \AA$, inferred from the X-ray single crystal structure of derriksite [10,11]. Raman band at $812 \mathrm{~cm}^{-1}$ was assigned to the $v_{1}$ $\left(\mathrm{UO}_{2}\right)^{2-}$ in marthozite [29] and haynesite [17]. In demesmaekerite, Raman band at $822 \mathrm{~cm}^{-1}$ and an infrared band at $819 \mathrm{~cm}^{-1}$ were attributed to the $v_{1}\left(\mathrm{UO}_{2}\right)^{2+}$ symmetric stretching vibration and an infrared band at $878 \mathrm{~cm}^{-1}$ to the $\left(\mathrm{UO}_{2}\right)^{2+}$ antisymmetric stretching vibration. Infrared bands at 879 and $820 \mathrm{~cm}^{-1}$ in the spectrum of marthozite [29] and at 898 and $815 \mathrm{~cm}^{-1}$ in the spectrum of piretite were attributed to the $v_{3}\left(\mathrm{UO}_{2}\right)^{2+}$ and $v_{1}\left(\mathrm{UO}_{2}\right)^{2+}$, respectively. Chukanov et al. [9] assigned the infrared band at $901 \mathrm{~cm}^{-1}$ in the spectrum of larisaite to the uranyl stretching vibration.

Raman band at 788 and infrared bands at 777 and $818 \mathrm{~cm}^{-1}$ may be attributed to the $v_{1}\left(\mathrm{SeO}_{3}\right)^{2-}$ symmetric stretching vibrations coinciding with the $v_{1}\left(\mathrm{UO}_{2}\right)^{2-}$ symmetric stretching vibrations, and infrared bands at 727 and 749 to the doubly degenerate $v_{3}\left(\mathrm{SeO}_{3}\right)^{2-}$ antisymmetric stretching vibrations. Raman band at $540 \mathrm{~cm}^{-1}$ is probably connected with the libration modes of water molecules or hydroxyl ions and/or to the $v$ (U$\mathrm{O}_{\text {ligand }}$ ) vibrations. Raman bands at $303 \mathrm{~cm}^{-1}$ and 378 and $471 \mathrm{~cm}^{-1}$ are attributed to the $v_{2}$ and $v_{4}\left(\mathrm{SeO}_{3}\right)^{2-}$ vibrations, respectively. The $v_{2}(\delta)\left(\mathrm{UO}_{2}\right)^{2+}$ bending vibrations were observed in the Raman spectrum at 282 and $257 \mathrm{~cm}^{-1}$, while the bands at 206 , 162,135 and $117 \mathrm{~cm}^{-1}$ may be assigned to the lattice vibrations. Infrared spectrum of $\mathrm{Sr}\left[\left(\mathrm{UO}_{2}\right)_{3} \mathrm{O}_{2}\left(\mathrm{SeO}_{3}\right)_{2}\right]\left(\mathrm{H}_{2} \mathrm{O}\right)_{4}$, observed in this region is as follows: $909 \mathrm{~cm}^{-1}\left(v_{3}\left(\mathrm{UO}_{2}\right)^{2+}\right), 865 \mathrm{~cm}^{-1}\left(v_{1}\left(\mathrm{UO}_{2}\right)^{2+}\right.$, $839,814,725$ and $615 \mathrm{~cm}^{-1}$ [31]. The structure of this synthetic compound, however, contains two-dimensional $\left[\left(\mathrm{UO}_{2}\right)_{3}\left(\mathrm{O}_{2}\right)(-\right.$ $\left.\left.\mathrm{SeO}_{3}\right)_{2}\right]^{2-}$ sheets with the same phosphuranylite anion sheet topology as found in the structures of guilleminite, marthozite and larisaite, and expected also in piretire and haynesite. This topology differs from that of derriksite and also demesmaekerite.

Infrared bands in the 982 to $1121 \mathrm{~cm}^{-1}$ and Raman band at $971 \mathrm{~cm}^{-1}$ are assigned to the $\delta \mathrm{Cu}-\mathrm{OH}$ bending vibrations. In this region, infrared bands were observed in demesmaekerite (infrared 1033, 1049, 1090, 1122, 1167 and $\left.1194 \mathrm{~cm}^{-1}\right)$, marthozite $(1120$, 1096, 1049 and $1027 \mathrm{~cm}^{-1}$ [29], larisaite (1044 and $1095 \mathrm{~cm}^{-1}$ ) [9] and haynesite (1168, 1116, 1081 and 1036) [17,27,32], which may be also attributed to the $\delta \mathrm{M}-\mathrm{OH}$ bending vibrations and/or combination bands. Chukanov et al. [9] assume that some of these bands together with some other at different wavenumbers may be connected with the $\left(\mathrm{H}_{3} \mathrm{O}\right)^{+}$bending vibrations and that especially haynesite contains hydroxonium cations and may be formulated as $\left(\mathrm{H}_{3} \mathrm{O}\right)_{2}\left[\left(\mathrm{UO}_{2}\right)_{3}(\mathrm{OH})_{4}\left(\mathrm{SeO}_{3}\right)_{2}\right] \cdot \mathrm{H}_{2} \mathrm{O}$. However, marthozite does not contain any hydroxonium ions and some bands in the mentioned region may be also observed. Chukanov et al. [9] assigned a band at $1732 \mathrm{~cm}^{-1}$ in the infrared spectrum of haynesite to the doubly degenerate bending vibration of hydroxonium ions. It is more probable that this infrared band may be attributed to the combination $\left(v_{1}+v_{3}\left(\mathrm{UO}_{2}\right)^{2+}\right)$ band, and some bands in the region $1000-1200 \mathrm{~cm}^{-1}$ may be connected with the combination $\left(v_{1}+v_{2}\right.$ $\left(\mathrm{UO}_{2}\right)^{2+}$ and/or $\left(v_{3}+v_{2}\left(\mathrm{UO}_{2}\right)^{2+}\right)$ bands. Frost et al. did not infer the presence of hydroxonium ions in the structure of haynesite in their Raman spectroscopic study of the uranyl selenite mineral haynesite [17]. In the case of derriksite, Raman bands at 881 and $943 \mathrm{~cm}^{-1}$ and infrared bands at 842 and $932 \mathrm{~cm}^{-1}$ may be related to the libration modes of water molecules and/or to the $\delta \mathrm{Cu}-\mathrm{OH}$ bending vibrations.

Infrared bands observed at 1319, 1385, $1505 \mathrm{~cm}^{-1}$ and Raman band at $1433 \mathrm{~cm}^{-1}$ may be connected with overtones and/or combination bands. Raman band at $1623 \mathrm{~cm}^{-1}$ and the infrared band at $1647 \mathrm{~cm}^{-1}$ are assigned to the $\delta$ bending vibration of hydrogen bonded water molecules.

Raman bands at 3530 and $3407 \mathrm{~cm}^{-1}$ and infrared bands at $3585,3562,3514$ and $3381 \mathrm{~cm}^{-1}$ are attributed to the $v \mathrm{OH}$ stretching vibrations of only weakly hydrogen bonded hydroxyls and those at 3247 and $2917 \mathrm{~cm}^{-1}$ and 3313 and $2978 \mathrm{~cm}^{-1}$, respectively, to the $v \mathrm{OH}$ stretching vibrations of hydrogen bonded water molecules. An infrared band at $2586 \mathrm{~cm}^{-1}$ may be connected with a combination band or an overtone. Approximate $\mathrm{O}-\mathrm{H} \cdots \mathrm{O}$ hydrogen bond lengths inferred from observed wavenumbers vary in the range 3.2-2.64 $\AA$ [33]. These values are close those inferred 
from the X-ray single crystal structure analysis of derriksite $[10,30]$. Observed number of the infrared bands in the region of $v$ $\mathrm{OH}$ stretching vibrations proves the presence of structurally nonequivalent hydroxyls and structurally nonequivalent water molecules (water of crystallization) in the derriksite unit cell $(Z=2)$.

\section{Conclusions}

(1) Raman and infrared spectra of uranyl selenite mineral derriksite were measured, tentatively interpreted and partly compared with the spectra of demesmaekerite, marthozite, larisaite, haynesite, piretite and synthetic $\mathrm{Sr}\left[\left(\mathrm{UO}_{2}\right)_{3} \mathrm{O}_{2}\left(\mathrm{SeO}_{3}\right)_{2}\right] \cdot\left(\mathrm{H}_{2} \mathrm{O}\right)_{4}$.

(2) The presence of symmetrically distinct hydrogen bonded molecule of water of crystallization and hydrogen bonded hydroxyls was inferred from the spectra.

(3) Approximate $\mathrm{U}-\mathrm{O}$ bond lengths in uranyls and $\mathrm{O}-\mathrm{H} \cdots \mathrm{O}$ hydrogen bond lengths were inferred from the Raman and infrared spectra with empirical relations by Bartlett and Cooney [30] and Libowitzky [33], respectively [34-36]. They are close to the $\mathrm{U}-\mathrm{O}$ and $\mathrm{O}-\mathrm{H} \cdots \mathrm{O}$ lengthes calculated on the basis of X-ray single crystal structure of derriksite [11].

\section{Acknowledgements}

The financial and infra-structure support of the Discipline of Nanotechnology and Molecular Science, Science and Engineering Faculty of the Queensland University of Technology, is gratefully acknowledged. The Australian Research Council (ARC) is thanked for funding the instrumentation. The authors would like to acknowledge the Center of Microscopy at the Universidade Federal de Minas Gerais (http://www.microscopia.ufmg.br) for providing the equipment and technical support for experiments involving electron microscopy. R. Scholz thanks to CNPq - Conselho Nacional de Desenvolvimento Científico e Tecnológico (Grant No. 306287/ 2012-9).

\section{Appendix A. Supplementary material}

Supplementary data associated with this article can be found, in the online version, at http://dx.doi.org/10.1016/j.saa.2013.08.026.

\section{References}

[1] M. Koskenlinna, Structural Features of Selenium(IV) Oxoanion Compounds, Thesis, Helsinky University of Technology, Espoo, 1996.

[2] L.B. Serezhkina, R.K. Rastsvetaeva, V.N. Serezhkin, Koord. Khim. 16 (1990) 1327-1339 (in Russian).

[3] P.C. Burns, Am. Mineral. 82 (1997) 1176-1186.

[4] P.C. Burns, Can. Mineral. 43 (2005) 1839-1894.

[5] P.C. Burns, Mater. Res. Soc. Symp. Proc. 802 (2004) 89-100.

[6] P.C. Burns, Rev. Mineral. 38 (1999) 23-90.

[7] R. Finch, T. Murakami, Rev. Mineral. 38 (1999) 91-179.

[8] J.F.W. Bowles, Handbook of mineralogy, in: J.W. Anthony, R.A. Bideaux, K.W. Bladh, M.C. Nichols (Eds.), Borates, Carbonates, Sulfates, vol. 5, Mineral Data Publishing, Tuscon, Arizona, USA, 2003.

[9] N.V. Chukanov, D.Y. Pushcharovsky, M. Pasero, S. Merlino, A.V. Barinova, S. Moeckel, I.V. Pekov, A.E. Zadov, V.T. Dubinchuk, Eur. J. Mineral. 16 (2004) $367-$ 374.

[10] R.P.F. Cesbron, T. Verbeek, Bull. Soc. Fr. 94 (1972) 534-537.

[11] D. Ginderow, F. Cesbron, Cryst. Struc. Commun. C39 (1983) 1605-1607.

[12] D. Ginderow, F. Cesbron, Cryst. Struc. Commun. C39 (1983) 824-827.

[13] M.A. Cooper, F.C. Hawthorne, Can. Mineral. 33 (1995) 1103-1109.

[14] M.A. Cooper, F.C. Hawthorne, Can. Mineral. 39 (2001) 797-807.

[15] M. Deliens, P. Piret, Haynesite, Can. Mineral. 29 (1991) 561-564.

[16] R. Vochten, N. Blaton, O. Peeters, M. Deliens, Can. Mineral. 34 (1996) $1317-$ 1322.

[17] R.L. Frost, M.L. Weier, B.J. Reddy, J. Čejka, J. Raman Spectrosc. 37 (2006) 816821.

[18] R.L. Frost, K.L. Erickson, M.L. Weier, O. Carmody, J. Čejka, J. Mol. Struc. 737 (2005) 173-181.

[19] R.L. Frost, M.L. Weier, T. Bostrom, J. Čejka, W. Martens, Neues Jahrb. Mineral. 181 (2005) 271-279.

[20] R.L. Frost, O. Carmody, K.L. Erickson, M.L. Weier, J. Čejka, J. Mol. Struc. 703 (2004) 47-54.

[21] R.L. Frost, D.A. Henry, K. Erickson, J. Raman Spectrosc. 35 (2004) 255-260.

[22] R.L. Frost, M.L. Weier, M.O. Adebajo, Thermochim. Acta 419 (2004) 119-129.

[23] R.L. Frost, K.L. Erickson, J. Čejka, B.J. Reddy, Spectrochim. Acta A61 (2005) 2702-2707.

[24] J. Čejka, Rev. Mineral. 38 (1999) 521-622.

[25] N.N. Greenwood, A. Earnshaw, Chemistry of Elements, Pergamon Press, Oxford, 1984.

[26] J. Čejka, J. Sejkora, R.L. Frost, E.C. Keeffe, J. Raman Spectrosc. 40 (2009) 15211526.

[27] R.L. Frost, J. Čejka, Spectrochim. Acta A71 (2009) 1959-1963.

[28] R.L. Frost, J. Čejka, M.J. Dickfos, J. Raman Spectrosc. 40 (2009) 476-480.

[29] R.L. Frost, J. Čejka, E.C. Keeffe, M.J. Dickfos, J. Raman Spectrosc. 39 (2008) 14131418.

[30] J.R. Bartlett, R.P. Cooney, J. Mol. Struc. 193 (1989) 295-300.

[31] P.M. Almond, T.E. Albrecht-Schmitt, Am. Mineral. 89 (2004) 976-980.

[32] R. Frost, B. Jagannadha Reddy, M. Dickfos, J. Near Infrared Spectrosc. 16 (2008) 455-469.

[33] E. Libowitzky, Monatshefte für Chem. 130 (1999) 1047-1059.

[34] R. Tali, V.V. Tabachenko, L.M. Kovba, Zh. Neorg. Khim. 38 (1993) 1450-1452 (in Russian).

[35] D.Y. Pushcharovsky, R.K. Rastsvetaeva, H. Sarp, J. Alloys Compd. 239 (1996) $23-26$.

[36] H. Yang, R.A. Jenkins, R.M. Thompson, R.T. Downs, S.H. Evans, E.M. Bloch, Am. Mineral. 97 (2012) 197-202. 